\title{
Thaw pond development and initial vegetation succession in experimental plots at a Siberian lowland tundra site
}

\author{
Bingxi Li • Monique M. P. D. Heijmans • Daan Blok • Peng Wang • Sergey V. Karsanaev • \\ Trofim C. Maximov • Jacobus van Huissteden • Frank Berendse
}

Received: 15 March 2017 / Accepted: 3 August 2017 / Published online: 22 August 2017

(C) The Author(s) 2017. This article is an open access publication

\begin{abstract}
Background and aims Permafrost degradation has the potential to change the Arctic tundra landscape. We observed rapid local thawing of ice-rich permafrost resulting in thaw pond formation, which was triggered by removal of the shrub cover in a field experiment. This study aimed to examine the rate of permafrost thaw and the initial vegetation succession after the permafrost collapse.
\end{abstract}

Responsible Editor: Zucong Cai.

Electronic supplementary material The online version of this article (https://doi.org/10.1007/s11104-017-3369-8) contains supplementary material, which is available to authorized users.

B. Li · M. M. P. D. Heijmans $(\bowtie) \cdot$ P. Wang $\cdot$ F. Berendse Plant Ecology and Nature Conservation Group, Wageningen University \& Research, Droevendaalsesteeg 3, 6708

PB Wageningen, The Netherlands

e-mail: Monique.Heijmans@wur.nl

D. Blok

Department of Physical Geography and Ecosystem Science, Lund University, Lund, Sweden

S. V. Karsanaev $\cdot$ T. C. Maximov

North-Eastern Federal University, 677000 Yakutsk, Russia

S. V. Karsanaev - T. C. Maximov

Institute for Biological Problems of the Cryolithozone, Siberian

Branch Russian Academy of Sciences, Yakutsk, Russia

J. van Huissteden

Earth and Climate Cluster, Department of Earth Sciences, Faculty of Earth and Life Sciences, Vrije Universiteit, Amsterdam, the Netherlands
Methods In the experiment, we measured changes in soil thaw depth, plant species cover and soil subsidence over nine years (2007-2015).

Results After abrupt initial thaw, soil subsidence in the removal plots continued indicating further thawing of permafrost albeit at a much slower pace: $1 \mathrm{~cm} \mathrm{y}^{-1}$ over 2012-2015 vs. $5 \mathrm{~cm} \mathrm{y}^{-1}$ over 2007-2012. Grass cover strongly increased after the initial shrub removal, but later declined with ponding of water in the subsiding removal plots. Sedges established and expanded in the wetter removal plots. Thereby, the removal plots have become increasingly similar to nearby 'natural' thaw ponds.

Conclusions The nine years of field observations in a unique shrub removal experiment at a Siberian tundra site document possible trajectories of small-scale permafrost collapse and the initial stage of vegetation recovery, which is essential knowledge for assessing future tundra landscape changes.

Keywords Arctic tundra $\cdot$ Betula nana $\cdot$ Permafrost degradation $\cdot$ Thermokarst $\cdot$ Vegetation dynamics

\section{Introduction}

The Arctic has experienced significant warming during the last three decades and it is projected that this trend will continue in the near future (IPCC 2013). The warming has triggered a series of marked changes in Arctic tundra ecosystems, including permafrost degradation (Hinzman et al. 2005; Jorgenson et al. 2015), 
acceleration of greenhouse gas release (IPCC 2013; Tarnocai et al. 2009) and shifts in vegetation composition (Chapin and Shaver 1996; Elmendorf et al. 2012; Fraser et al. 2014; Jia et al. 2009; Tape et al. 2006). One of the most striking changes in vegetation composition is the extensive shrub expansion that has been observed in many parts of the Arctic (Myers-Smith et al. 2011). Along the Arctic tree line, tree and shrub expansion seem to be higher in upland tundra landscapes than in lowland tundra (Frost and Epstein 2014).

Permafrost thawing is often represented as a gradual thawing (e.g. Schaefer et al. 2011). However, thawing can be abrupt at the local scale, resulting in permafrost degradation features such as ice wedge troughs, thaw slumps, thaw ponds and ultimately thaw lakes (Schuur et al. 2015). When the permafrost is ice-rich, increased thawing in summer can result in melting of ice in the top of the permafrost, causing surface subsidence and the creation of depressions with standing water. Occurrence of ice wedge degradation and increasing numbers of thaw ponds or thermokarst pits have been reported for Siberian, Alaskan and Canadian Arctic tundra sites (Beck et al. 2015; Jorgenson and Grosse 2016; Jorgenson et al. 2010; Liljedahl et al. 2016; Schuur et al. 2015). Increased small-scale permafrost degradation has consequences for the hydrology of the landscape and the emission of greenhouse gases (van Huissteden and Dolman 2012).

Thaw ponds are prominent features at our study site in Siberian lowland tundra, and their number has doubled between the 1970s and 2010 based on a comparison of satellite images (van Huissteden, unpublished data). The ice content in the top layer of the permafrost underlying this region can reach as high as $80 \%$ by volume (Iwahana et al. 2014; Kanevskiy et al. 2013), making the permafrost highly susceptible to thaw subsidence under climate warming. The melting of ice in the top layer of permafrost can lead to soil subsidence and ponding of water. The depressions evolving from soil subsidence effectively trap snow and water which contribute to further thawing and thaw pond formation (Nauta et al. 2015). Little is known about what triggered the local abrupt thaw, how these thaw ponds have developed over time and how vegetation succession and recovery eventually takes place.

To examine the impact of vegetation change on seasonal thawing of permafrost, we set up a Betula nana $\mathrm{L}$. shrub removal experiment at a northeast Siberian tundra site (Blok et al. 2010). After an initial increase in thaw depth resulting from the removal of the $B$. nana dwarf shrub cover (first phase), we observed local permafrost collapse and soil subsidence by the 5 th year (second phase). The soil subsidence in the removal treatment, resulted in ponding of water that shifted the removal plots from a net sink into a source of methane (Nauta et al. 2015). This study reports on the third phase in which the thawing is slowing down, but the vegetation composition is still changing in response to the ponding of water in the subsiding removal plots. To provide a broader context for our results in the experiment, we compared the vegetation development in our experiment plots with the vegetation composition in natural thaw ponds, in which the small-scale permafrost collapse had unlikely been caused by human disturbance.

The goal of this study was to gain insight into further thaw pond development and into the initial stage of vegetation succession after abrupt permafrost thaw by examining the changes in thaw depth, soil subsidence and vegetation composition in the B. nana removal experiment over a period of 9 years. We hypothesized that after 2012 1) soil subsidence continued in the $B$. nana removal plots, 2) vegetation composition shifted further, and 3) became more similar to the vegetation of the natural thaw ponds occurring in the same drained thaw lake basin as the experimental plots.

\section{Materials and methods}

\section{Site description}

The research site is part of the Chokurdakh Scientific Tundra Station, located in the Kytalyk Nature Reserve in the lowlands of the Indigirka River, Sakha Republic, Russian Federation $\left(70^{\circ} 49^{\prime} 45^{\prime \prime} \mathrm{N}, 147^{\circ} 28^{\prime}\right.$ 47" E; Fig. 1). The study area consists of poorlydrained lowland tundra and is characterized by thick continuous permafrost with a shallow active layer on top. Ice-rich Yedoma deposits and drained lake basins are abundant in the thermokarst-affected landscape in the lowland regions in eastern Siberia (Olefeldt et al. 2016). At locations close to our study site, ice contents of $40-95 \%$ by volume have been measured (Iwahana et al. 2014). The field experiment was set up in a drained thaw lake basin. The microtopography within the basin consists mostly of 


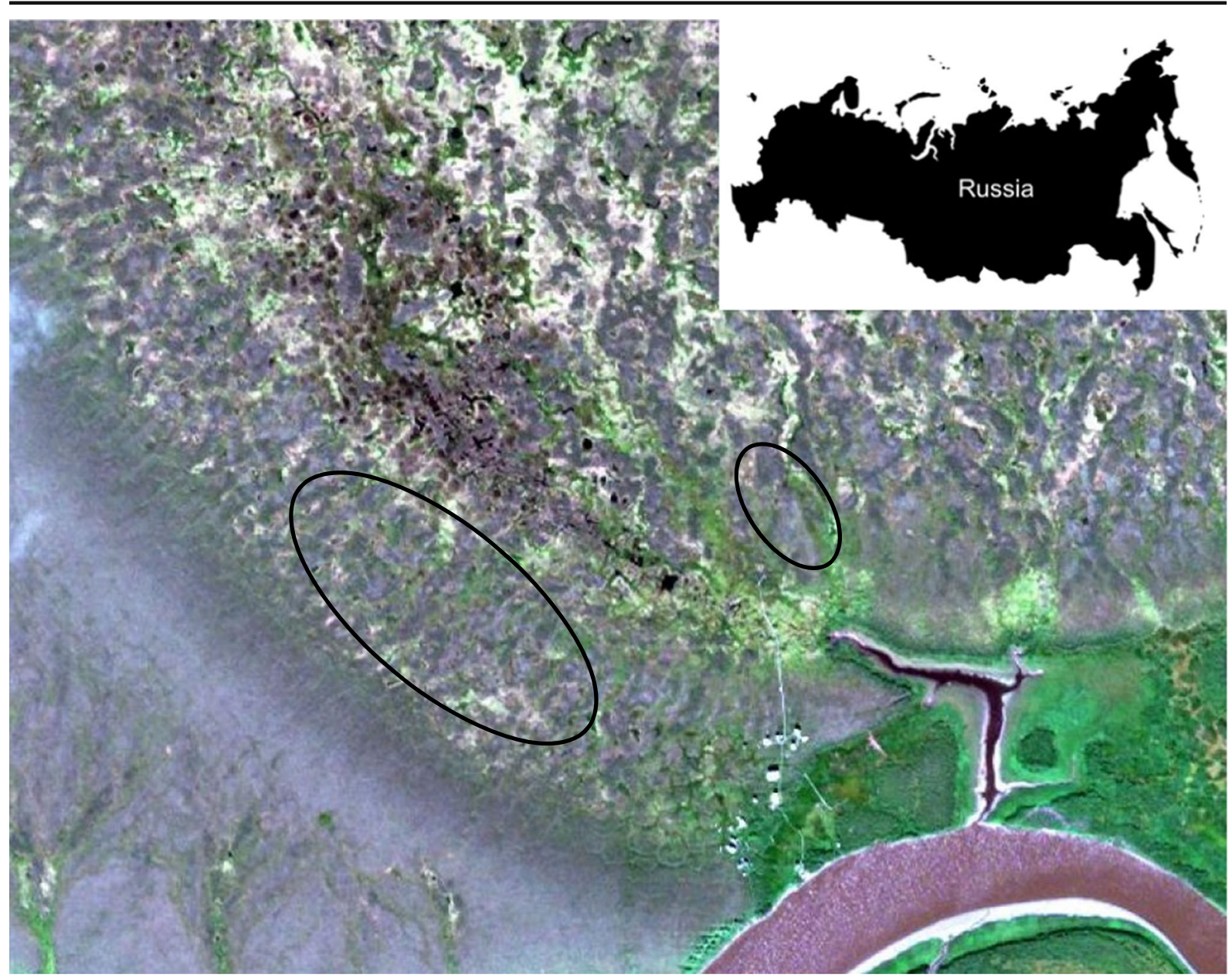

Fig. 1 Location of the Kytalyk study site near the town of Chokurdakh, Sakha Republic (Yakutia), Russian Federation (white star in map of Russia). The satellite image (GeoEye) shows part of the drained thaw lake basin, with the location of the experiment plots (left oval) close to the margin of the lake basin and the natural thaw ponds (smaller right oval). Inbetween the experiment plots and the natural thaw ponds is a wetter area with ice-wedge polygons, many of them in a degraded stage. The lower left corner is a Pleistocene Yedoma remnant surface. The river is the Berelekh River which contributes to the Indigirka River. Grey colour is (dwarf) shrub vegetation; white colour is Sphagnum moss carpets and green colour is sedge vegetation within the drained lake basin elevated shrub patches dominated by B. nana (dwarf birch) shrubs surrounded by a diffuse drainage network of wet depressions dominated by the graminoid species Eriophorum angustifolium Honck. Ice-wedge low-center polygons are abundant in the wetter part of the drained lake basin, many of the polygons are in a degraded stage (Fig. 1, Teltewskoi et al. 2016). Both the experiment plots and natural thaw ponds are located on irregular frost mounds dominated by B. nana (Siewert et al. 2015).

The vegetation of the research area is classified as tussock-sedge tundra, dominated by Eriophorum spp. sedges and deciduous shrubs like Betula nana and moss (G4), in the Circumpolar Arctic Vegetation Map (Walker et al. 2005). B. nana is dominant on slightly elevated shrub patches, while Sphagnum mosses and Eriophorum sedges are the most common plant types in waterlogged depressions surrounding the shrub patches and in thaw ponds. The research site is in the Low Arctic climate zone with Chokurdakh (WMO station 21,946) mean annual air temperature of $-13.4^{\circ} \mathrm{C}$ (1981-2010) and mean annual precipitation of $196 \mathrm{~mm}$ (1981-2010). An extensive site description can be found in Nauta et al. (2015). 
Removal experiment and natural thaw ponds

The Betula removal experiment was set up in the summer of 2007. For this experiment, 10 dwarf-shrub plots ( 5 pairs) were selected in the former bed of a thermokarst lake. In each plot pair, one was the control plot and the other the removal plot. B. nana was the dominant species in all plots. In July 2007 the aboveground biomass of $B$. nana in the 10-m diameter removal plots was clipped manually by using branch clippers. Resprouted B. nana shoots (from belowground coarse roots) were clipped again in the summer of 2010 and 2013. In 2013, we selected four 'natural' thaw ponds with similar size in the same drained thaw lake basin, for comparison with the subsided B. nana removal plots. The word "natural" is used here to indicate the contrast with the developing thaw ponds in the experiment. We do not know the mechanism that triggered the abrupt permafrost thaw in the studied thaw ponds, but we presume that human-induced vegetation disturbance was unlikely.

Thaw depth and surface elevation

We measured the thaw depth of each plot in the B. nana removal experiment in late July of each year. Thaw depth was measured from the top of the moss/litter/ bare-soil surface to the top of the permafrost at nine points within each plot using a bluntly tipped steel probe. We compared the thaw depth of the control plots and the removal plots using RM-ANOVA with year as repeated factor within plots. ALT differences between the control plots and the removal plots in specific years were analyzed using one-way ANOVA tests.

The relative surface elevation of each plot was measured in 2015 using an optical levelling instrument (Kompensator-Nivellier NI 025, Jena, Germany). and compared to the measurements in 2012, published in Nauta et al. (2015). Surface elevation was measured along two transects perpendicular to each other, extending four meter beyond the plot borders. We followed the same procedures and steps that were made in the preceding years, guaranteeing that the data series were comparable, although the measurements had not been done at exactly the same spots within the transects. Each transect had 19 evenly distributed spots every $1 \mathrm{~m}$ : eleven spots within the 10 -m diameter plot, and eight spots outside the plot area ( 4 spots per side). To calculate the relative elevation within the plot, we used the mean elevation of the 16 spots just outside the plot as the $0-\mathrm{m}$ reference, assuming the elevation of these spots had changed little between 2012 and 2015. In this way, we transformed the original elevation data into the relative elevation data series that could be used to compare the treatments. We used linear mixed models to test for changes in relative elevation between 2012 and 2015 in the control and removal plots. In SPSS, plot was treated as the subject, with year and distance to plot center repeated within plot, and treatment (control, removal), year $(2012,2015)$ and distance to plot center $(0$ to $5 \mathrm{~m}$ ) were the fixed factors. RM-ANOVA tests were used for comparing the elevations of each plot in 2012 and 2015.

Vegetation composition

The point quadrat method was used to measure the vegetation composition of each plot annually in midJuly. We assessed the cover of vascular plant species and moss and lichen groups of each plot by recording the presence at 169 evenly distributed points $(13 \times 13$ matrix) covering $10 \times 10 \mathrm{~m}$. We vertically lowered a thin metal pin and recorded all the plant species that the pin touched while it was brought down at each point, with a maximum of one hit per species per point. As the $B$. nana aboveground biomass was removed in circular 10-m diameter plots, we only used the records inside the 10-m diameter plot for the analysis of vegetation changes over time in the control and removal plots. The cover of each plant species/group was defined as the number of times this plant species/group was recorded per plot divided by the total number of points within the $10-\mathrm{m}$ diameter plot, resulting in plant species/type cover values between $0 \%$ and $100 \%$. The same method was used for measuring the vegetation composition in the natural thaw ponds in mid-July of 2013. The vegetation composition was measured before the $B$. nana removal treatment in the removal plots in 2007 and 2010 but after the treatment in 2013.

To illustrate the changes in vegetation composition over time, we made mosaic-like vegetation maps using "ggplot2" (Wickham 2016), "grid” (Murrell 2003), "Rcolorbrewer" (Neuwirth 2014) and "scale" (Wickham 2012) packages from the R Project for Statistical Computing. The top species hit at each point from 2007, 2009, 2011, 2013 and 2015 was used for the vegetation maps. We categorized the plant species into 14 groups with unique colors (B. nana, Salix spp., 
other shrub, grass, sedge, forbs, lichen, non-Sphagnum moss, Sphagnum, water/mud (bare soil) surface, shrub litter, grass litter, sedge litter). The "other shrub" group included Ledum palustre ssp. decumbens (Ait.) Hult., Rubus chamaemorus L., Vaccinium uliginosum L., and Vaccinium vitis-idaea L.. The main grass species were Arctagrostis latifolia (R.Br.) Griseb and Calamagrostis holmii Lange. The "sedge" group included Eriophorum angustifolium Honck., Eriophorum vaginatum L., and Carex aquatilis var. minor Boott.

We compared the cover of each plant group in the control and the removal plots over the entire time series and annually using Repeated Measures ANOVA (RMANOVA) and one-way ANOVA tests, respectively, in SPSS software (IBM SPSS Statistics for Windows, ver. 22.0; IBM Corp., Armonk, NY, USA). The normal distribution of each variable was examined before this test and the tests mentioned later. All data series whose residuals were not normally distributed were logtransformed and their residuals were normalized.

To visualize the vegetation shift in the two plot types between 2007 and 2015 and the similarity with the natural thaw ponds, we used Detrended Correspondence Analysis in CANOCO (canonical community ordination) software (version 4.5, Microcomputer Power, NY, USA). The same plant groups used in the vegetation maps were also implemented here. We calculated the average cover of each plant group in the control and the removal plots for each year and used the annual average coverages in CANOCO for the ordination scores. We used CanoDraw software (Part of CANOCO) for the final DCA figure. We included the plant group cover data of the four natural thaw ponds (measured in 2013) in the DCA figure for comparison with the removal plots. Finally, we made a dendrogram figure to explore the similarity in vegetation composition of the individual plots, 10 experiment plots and 4 natural thaw ponds, based on correspondence analysis using the vegetation composition of the plots (in SPSS software). The point quadrat data measured in 2013 were used in this test.

\section{Results}

Abiotic changes in the Betula nana removal experiment

The soil subsidence in the removal plots continued after 2012, resulting in further thaw pond development (Fig. 2). Surface elevation changes between 2012 and 2015 depended on the removal treatment (treatment $\times$ year interaction: $F_{1,118}=4.68, p=0.033$ ). The removal plots had experienced significant elevation changes between 2012 and 2015 (control plots: $F_{1,58}=26.20, p=0.081$; removal plots: $F_{1,58}=13.10, p=0.001$, Fig. 3, Appendix Figure 9). The subsidence between 2012 and 2015 of the removal plots was significantly larger than that of the control plots (removal plots: $7.6 \pm 1.3 \mathrm{~cm}$; control plots: $\left.2.3 \pm 0.6 \mathrm{~cm} ; F_{1,8}=26.35, p<0.001\right)$. In the removal plots, distance from plot center significantly affected the elevation changes (control plots: $F_{5,54}=3.20, p=0.844$; removal plots: $F_{5,54}=4.31$, $p=0.011$ ). The subsidence progressively increased from the margins to the centers of the removal plots (slope $=1.5 \mathrm{~cm} \mathrm{~m}^{-1}, R^{2}=0.93$ ).

In all eight years after the initial removal of the $B$. nana cover, the late-July thaw depth in the removal plots was significantly deeper than in the control plots $\left(F_{1,8}=105.92, p<0.001\right.$ in 2015, Fig. 4). After 2012, thaw depth in the removal plots became stable (slope $=0.26 \mathrm{~cm} \mathrm{y}^{-1}, R^{2}=0.01$ ), which contrasts with the continuous increase in thaw depth from 2009 to 2012 (slope $=5.6 \mathrm{~cm} \mathrm{y}^{-1}, R^{2}=0.95$ ). Similarly, the difference in thaw depth between control and removal plots did not increase further after 2012 (Fig. 4).

As a result of soil subsidence and increased thaw depth in the removal plots relative to the control plots, the permafrost table was lowered by $30 \mathrm{~cm}$ on average over 8 years in the removal plots (Fig. 5). However, after 2012 the permafrost thawing rate strongly declined from $5.4 \mathrm{~cm} \mathrm{y}^{-1}$ over 2007-2012 to $1.0 \mathrm{~cm} \mathrm{y}^{-1}$ over 20122015.

Vegetation shifts in the Betula nana removal experiment

The vegetation composition in the removal plots continued to change in the period 2012-2015, whereas the vegetation composition in the control plots was rather stable with a high cover of B. nana (Fig. 6, table S1). The clipping of $B$. nana dwarf shrubs drastically reduced its cover in the removal plots, as intended, from $78 \% \pm 6 \%$ in 2007 to $13 \% \pm 1 \%$ in 2015 (Fig. 6). During this process, the regrowth of B. nana in the removal plots was substantial in 2009 and 2010 but the $B$. nana cover became increasingly smaller after the removal of regrowth in 2010 and 2013 (Fig. 6). The grass cover strongly increased from 2009, reaching a peak in $2011(55 \% \pm 6 \%)$, but declined thereafter and dropped back to 


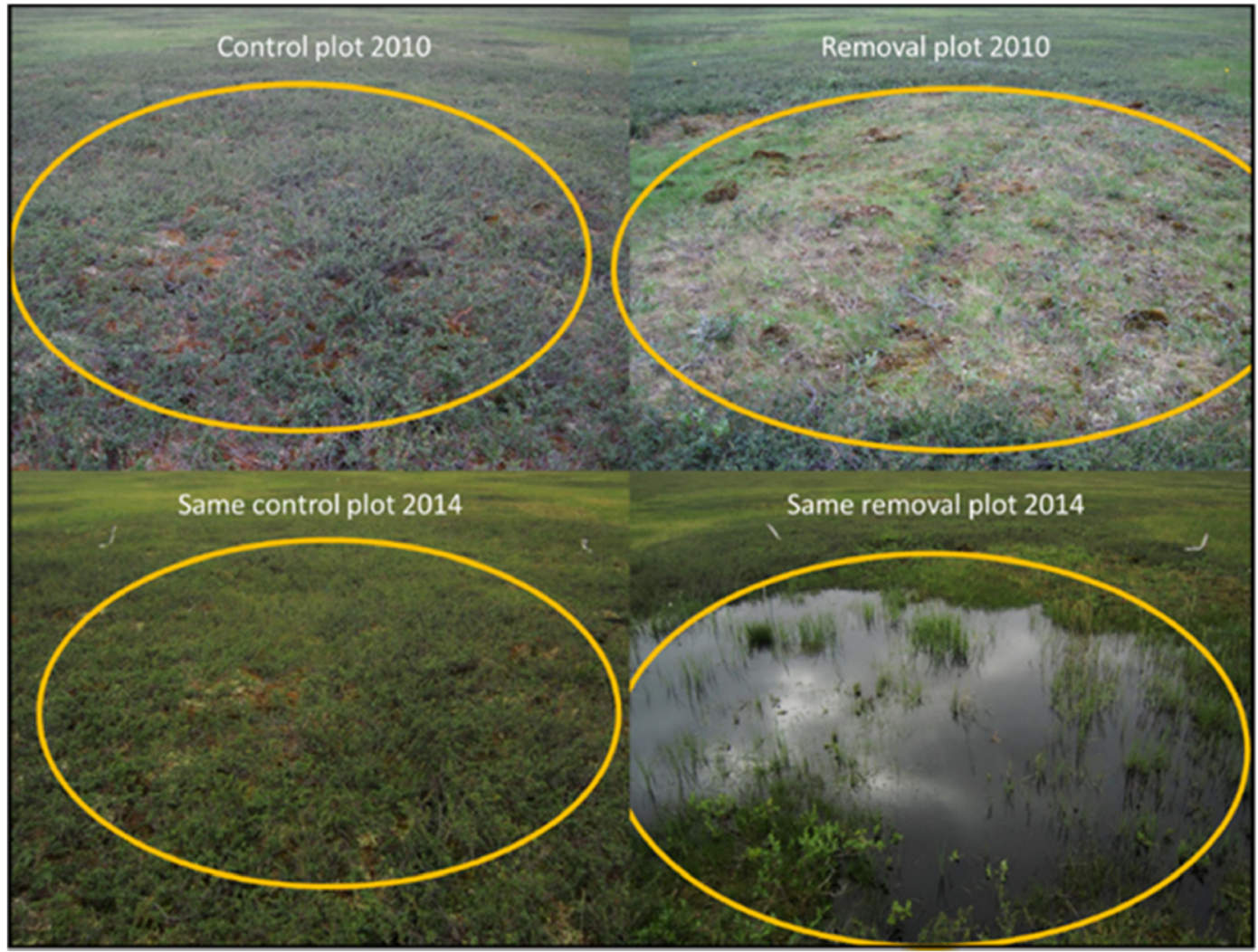

Fig. 2 One pair of a control plot with dense Betula nana shrub vegetation (left) and a 10-m diameter removal plot in which the aboveground biomass of $B$. nana had been removed (right). Photos were taken from the same position in 2010 and 2014.

$23 \% \pm 6 \%$ in 2015 . The removal of B. nana also changed the cover of sedges and mud/water significantly, related to the soil subsidence which created wet depressions/ponds. The groups mud/water and sedges were present in the removal plots since 2011 , and both reached around $20 \%$ cover in 2015 (Fig. 6; mud/water: $22 \% \pm 12 \%$, sedge: $20 \% \pm 5 \%$ ).
The control plot has not changed, whereas this removal plot has turned into a thaw pond. The yellow circle indicates the area of the 10-m diameter plot

The mosaic-like vegetation maps illustrate the changes in species composition in the five removal plots over the years (Fig. 7). In all five removal plots the canopy was dominated by $B$. nana shrubs before the $B$. nana removal. With the decrease of $B$. nana, initially the grasses strongly increased in cover, becoming the most common plant type in all five removal plots in 2011
Fig. 3 The relative surface elevation in 2012 (red lines) and 2015 (blue lines) of the control plots (left panel) and the B. nana shrub removal plots (right panel) at increasing distance from the plot center. Data are mean values \pm s.e.m., $n=5$ plots. The average elevation at 6-9 $\mathrm{m}$ from the plot center ( $n=16$ spots) was taken as the zero reference for each plot

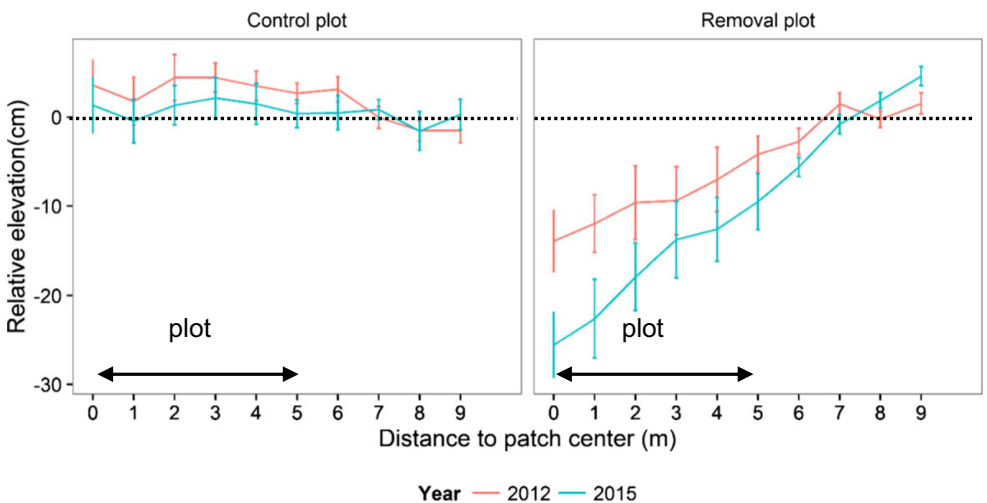


Fig. 4 Late-July thaw depth or active layer thickness (ALT) in the $B$. nana shrub removal plots (Removal) and control plots (Control) from the start of the experiment (2007) until 2015. Data are mean values \pm s.e.m., $n=5$ plots. $* * *$ and $* * *$ indicate significant differences between the two treatments $(p<0.05$, $p<0.01, p<0.001$, respectively)



(Fig. 7). Sedges first appeared along the margin of removal plot 3 in 2009 and became the most common plant group in the canopy in removal plot $2(23 \%)$ and 3 $(31 \%)$ in 2015 , while the sedge cover in the other three plots varied between $10 \%$ and $15 \%$ (Fig. 7). Moreover, $41 \%$ of the area of removal plot 5 was bare mud or water in 2015. In the natural thaw ponds, sedge was the dominant plant group, accompanied by some Sphagnum moss in pond 3 and 4 , while $B$. nana was dominant just outside the pond (Fig. 7).

\section{Comparison of removal plots with natural thaw ponds}

The vegetation composition of the control plots did not change much over the years of study. In contrast, the removal plots had experienced a large vegetation shift, from B. nana dominated plots in 2007 before the removal treatment to plots characterized by grasses and Salix shrubs in 2013 (Fig. 8). The cover of sedges and mud/water increased as well, indicating that the removal plots became more similar to the
Fig. 5 Soil subsidence and the thawing of permafrost in the B. nana shrub removal plots (2007-2015). The black line indicates the lowering of the soil surface (soil subsidence), based on relative elevation

measurements in 2012 and 2015. The grey line indicates the lowering of the permafrost table, calculated as the sum of soil subsidence and the increase in thaw depth (ALT, measured relative to the soil surface) due to the removal treatment

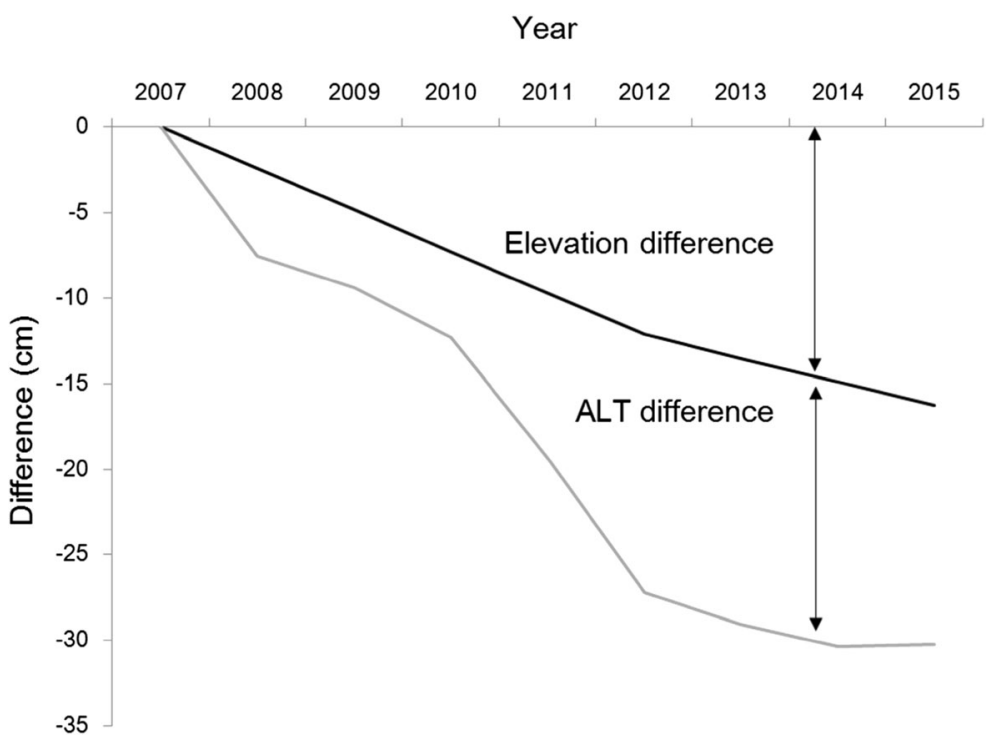




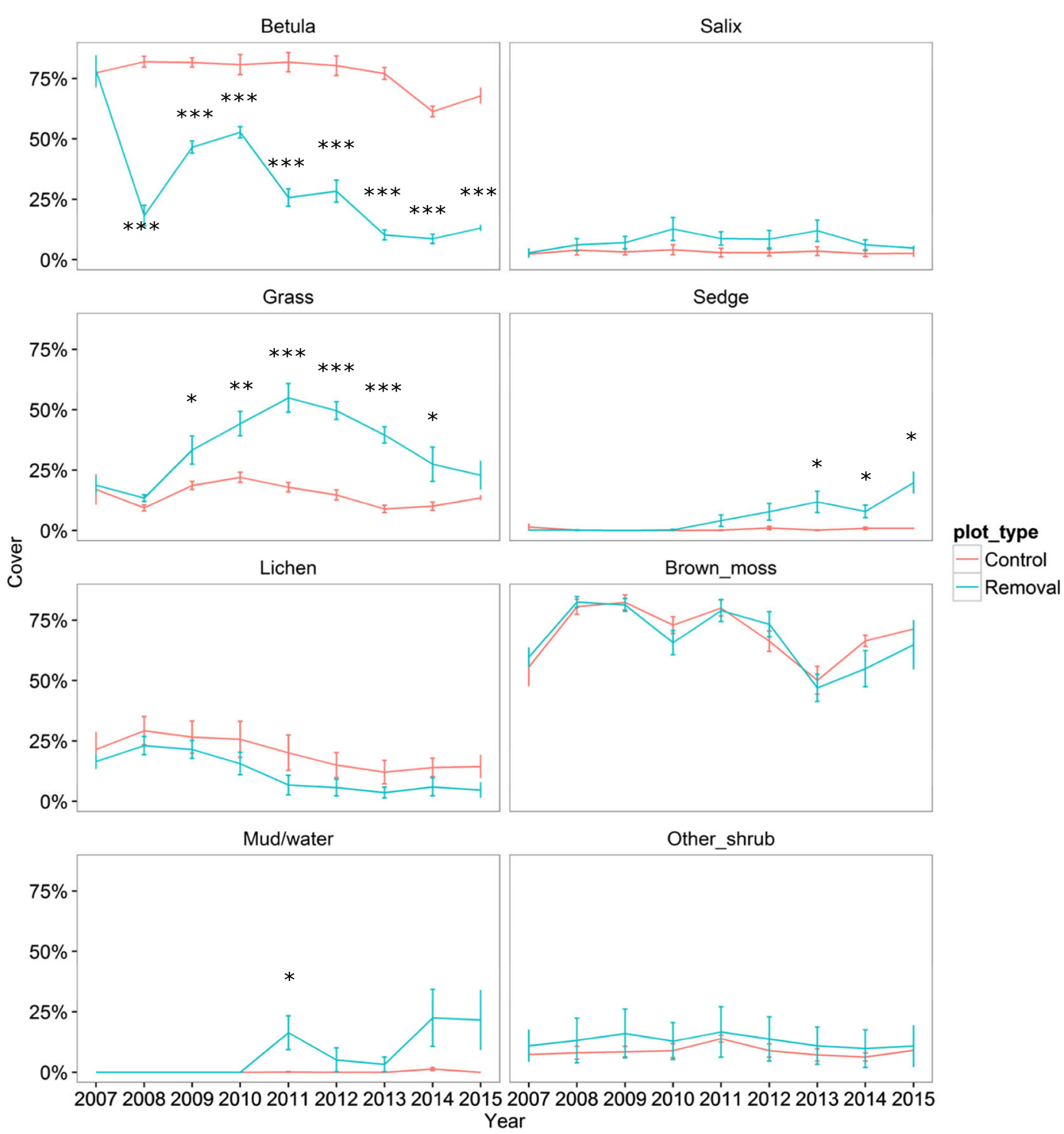

Fig. 6 Projected cover (\%) of seven plant groups and exposed $\mathrm{mud} /$ water in the B. nana shrub removal experiment between 2007 and 2015. Data are mean values \pm s.e.m., $n=5$ plots. The blue lines indicate the cover in the $B$. nana removal plots and the red lines are the values in the control plots. *,** and $* * *$ indicate significant differences between the two treatments $(p<0.05$,

natural thaw ponds, which were characterized by sedges, Sphagnum and exposed mud and water surfaces. Thaw ponds 1 and 4 seemed more similar to the removal plots, compared to the other two thaw ponds. The dendrogram providing the relationships of the vegetation compositions of the individual control, removal and natural thaw pond plots in 2013, shows that the control plots were clearly separated $p<0.01, p<0.001$, respectively). Aboveground biomass of B. nana had been clipped off in 2007, 2010 and 2013. In 2007 and 2010 the vegetation measurements took place before the removal, in 2013 the vegetation survey was made after the removal of regrowth

from the removal plots and thaw ponds (Appendix Figure 10).

\section{Discussion}

After 2012, the differences in thaw depth between the control and removal plots stabilized. However, as thaw 



09 Removal1
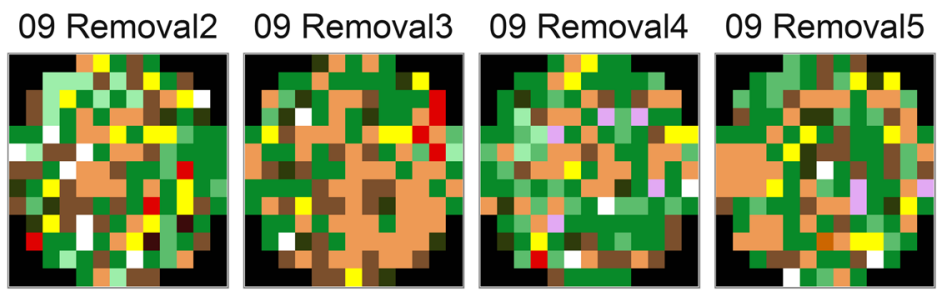

11 Removal1
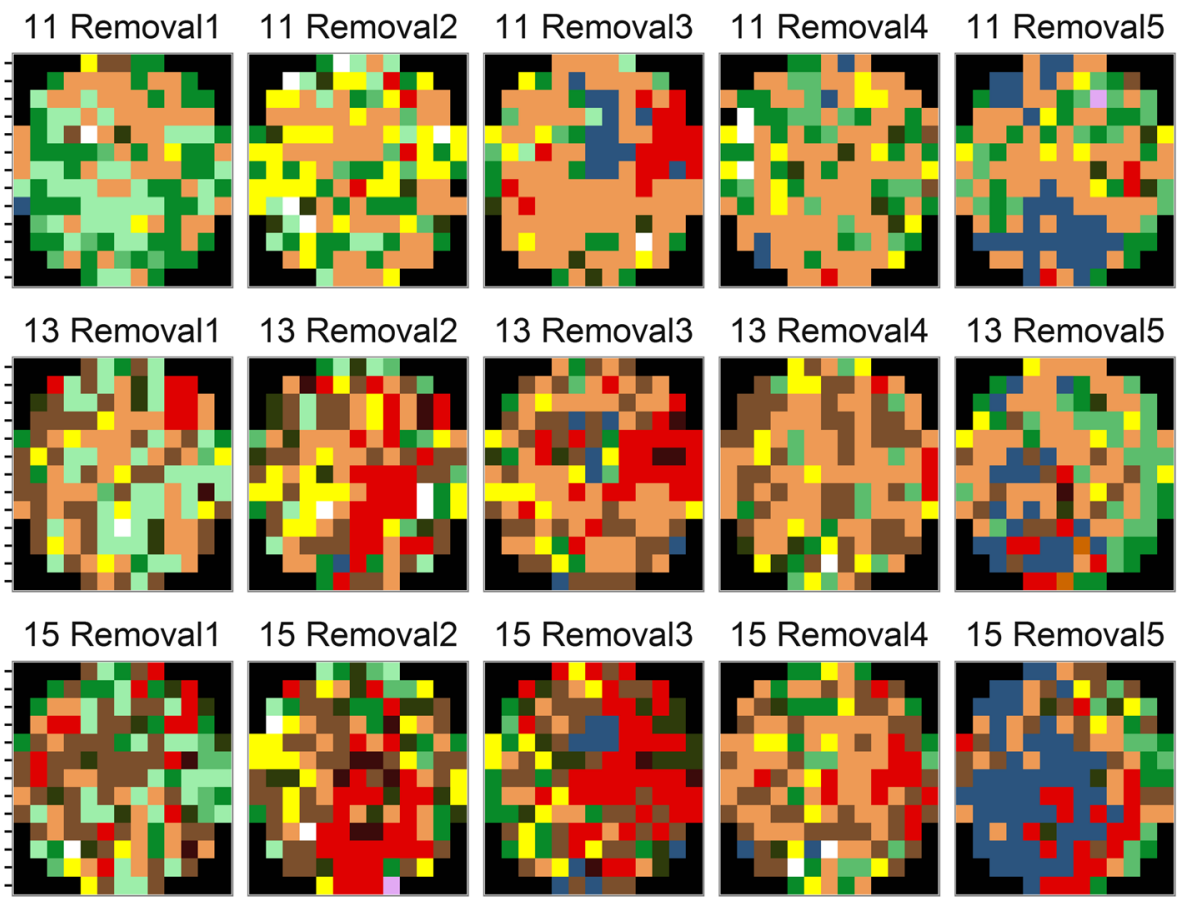

\section{species}

Betula nana

Salix spp.

Dwarf shrub

Grass

Sedge

Shrub litter

Grass litter

Sedge litter

Sphagnum moss

Non-Sphagnum moss

Soil/Water

Lichen

Forbs

Outside plot



13 Pond2

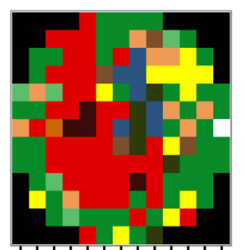

13 Pond3

13 Pond4
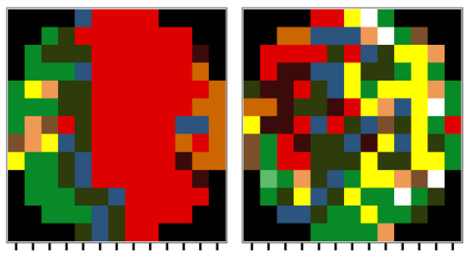

Fig. 7 The vegetation composition, as seen from above the canopy, of the five $B$. nana removal plots and four natural thaw ponds outside the experiment area, based on the top hit of the point quadrat measurements (B. nana removal plots in 2007, 2009,

2011, 2013 and 2015 and natural thaw ponds in 2013). The colors of the mosaic represent different plant groups. The black pixels indicate the area outside the $10-\mathrm{m}$ diameter plot 


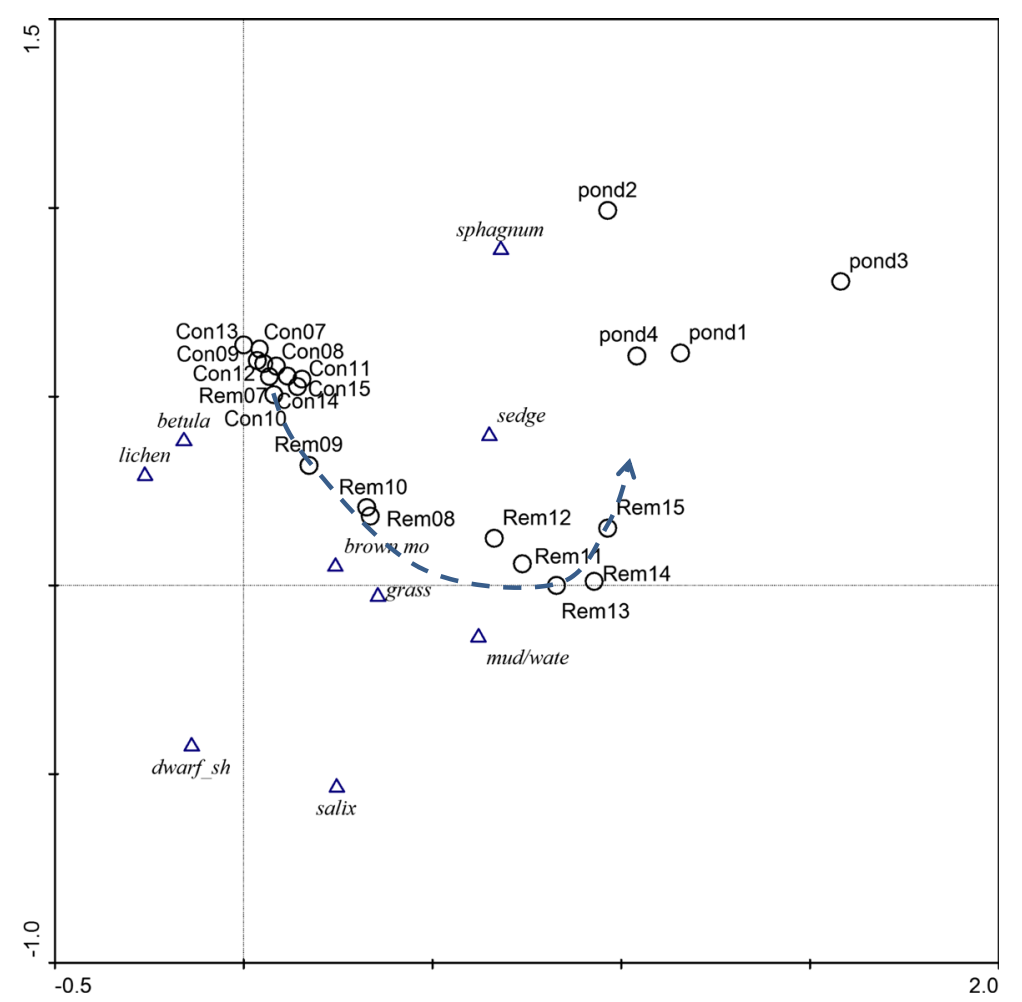

Fig. 8 The changes in vegetation composition changes over 2007-2015 in the B. nana shrub removal experiment, based on a Detrended Correspondence Analysis (DCA) of the point-quadrat data, in the control plots (Con) and the B. nana removal plots (Rem). The circles labeled pond represent the four natural thaw ponds, measured in 2013. The triangels represent the major plant groups: betula: Betula nana; salix: Salix spp.; mud/wate: exposed

depth is measured relative to the ground surface, the further soil subsidence after 2012 implied that the permafrost thaw in the removal plots had continued, although at a much slower pace. The increased area of standing water and exposed mud confirmed further subsidence and increasing wetness in the removal plots. Nauta et al. (2015) argued that a positive feedback loop between thawing and the increasing water area developed in the removal plots. Water is trapped in the depressions, and the pooling of water accelerated local thawing, due to the strong reduction in albedo when green or brown vegetation is replaced by the dark water surface. The collapsed concave plots also trap more insulating snow in winter, accelerating the positive feedback between permafrost thaw and soil subsidence (Nauta et al. 2015).

The vegetation composition of the removal plots shifted between 2007 and 2015 in response to the removal of $B$. nana and increasing wetness, while the mud/water; dwarf_sh: other dwarf shrub (Vaccinium spp., Rubus chamaemorus and Ledum palustre ssp. decumbens); grass: grass (mainly Arctagrostis latifolia); sedge: sedge (mainly Eriophorum angustifolium); brown_mo: moss (excluding Sphagnum spp.); lichen: lichen; sphagnum: Sphagnum spp. moss. The dashed arrow indicates the direction of change in the vegetation composition in the removal plots over the years

vegetation composition in the control plots was rather stable. The grass plant group replaced $B$. nana shrubs and became the most common species in 2011 but decreased afterwards. The removal of the aboveground biomass of the highly dominant $B$. nana probably increased light and nutrient availability for the other species that were already present.

In general, soil nutrient limitation, especially of phosphorus and nitrogen, markedly suppresses the growth and the reproduction of plants in the Arctic tundra (Dormann and Woodin 2002; Shaver et al. 1998). Several nutrient addition experiments (Robinson et al. 1995; Shaver and Chapin 1986) in the Arctic tundra have shown that compared with other plant types, grasses could benefit most from extra soil nutrients (nitrogen and phosphorus). The biomass of the grasses, which was low in the unfertilized plots, increased more than 15fold in fertilized plots of these experiments. The fast increase of $A$. latifolia, can probably be attributed to its 
good ability to acquire newly available nutrients by adjusting its vertical distribution of fine roots to soil depths where the newly available nutrients are (Wang et al. 2017).

In comparison to dwarf shrubs like $B$. nana and $V$. vitis-idaea, grasses and sedges have deeper roots (Miller et al. 1982; Shaver and Cutler 1979; Wang et al. 2016), and thus have better opportunities to reach the nutrients in the newly thawed deep soil (Oulehle et al. 2016). Low shrub canopies in tundra reduce local permafrost thawing during the growing season, maintaining shallower thaw depths than the areas dominated by other plant types (Blok et al. 2010; Wang et al. 2016). The deeper thaw depths in the removal plots imply that nutrient availability for roots growing in the deep soil has probably been higher in the removal plots. In our study, the cover of the grasses in the removal plots, which was initially below $20 \%$, reached over $50 \%$ in the 5 th year after the start of the experiment. Thus, the grass A. latifolia proved to be a fast responder to rapidly changing soil conditions in the removal plots, which is similar to its response in a deep soil heating and fertilization experiment at the Kytalyk site (Wang et al. 2017). This grass species might be an indicator of recent abrupt thawing of the permafrost. A. latifolia has earlier been identified as a species that responds to disturbances (Kemper and Macdonald 2009).

Subsequently, the rapid rise in soil moisture content and the increased area of standing water in the removal plots probably enabled the establishment and growth of sedges, mainly E. angustifolium, led to a decrease in grasses, and prevented the re-growth of the B. nana shrubs in the removal plots simultaneously. The exceptionally high water/mud cover in 2011 in the removal plots (Fig. 6) probably resulted from the high summer rainfall $(158 \mathrm{~mm}$ in JuneAugust), which was almost twice as high as the mean summer rainfall $(84 \mathrm{~mm})$ between 2008 and 2015. In tundra, E. angustifolium sedges and $B$. nana shrubs occupy areas with distinctively different soil moisture conditions. E. angustifolium prefers the low-lying waterlogged areas, while $B$. nana favors the elevated, well-drained hummocks (Bliss 1956). The extremely high soil moisture might have killed the surviving belowground stems of B. nana shrubs in the removal plots, stopping the regrowth of B. nana consequently (Fig. 6). E. angustifolium was not present in the plots at the start of the experiment, but was abundant in nearby depressions surrounding the slightly elevated B. nana shrub patches, and perhaps needed some time to get established in the wet parts of the removal plots. It is not clear why A. latifolia in the removal plots is on the decline in the recent years (Fig. 6). Probably, it cannot tolerate the increasingly permanently water-saturated conditions in the developing thaw ponds and is subsequently being replaced by E. angustifolium. This species is known to withstand anaerobic conditions due to its aerenchymous tissues which conduct oxygen from the atmosphere to the anaerobic root zone. Ponding water has been consistently observed in the removal plots since 2011, so we expected the sedge E. angustifolium to become more common in the removal plots.

The direction of the vegetation shifts was similar in all five removal plots, although the pace of the shifts differed. We suggest that the differences in present vegetation composition among the removal plots are mainly the consequence of the different substrate conditions. The ice content of the permafrost underlying lowland tundra often reaches as high as $80 \%$ by volume in the top of the permafrost (Ping et al. 2013). Near our study site, the ice content in permafrost was on average $75 \%$ by volume (Iwahana et al. 2014). Nevertheless, the ice content in the ice-rich permafrost is not evenly distributed. The permafrost with higher ice content collapses more rapidly, as the melting of the ice drives the soil subsidence. Accordingly, the removal plots with higher ice contents in permafrost may have subsided more, resulting in higher soil moisture contents in the new depressions. As tundra plants are usually sensitive to changes in soil moisture related to changes in relative surface height resulting from small-scale permafrost degradation, different soil moisture levels largely determined the variation in plant species composition of the different removal plots (Bliss 1956; de Klerk et al. 2014; Jorgenson et al. 2006; Wolter et al. 2016).

Although the removal plots are still different in comparison to the natural thaw ponds, it is clear that they resemble more and more thaw ponds 1 and 4, due to increasing sedge cover and an increased area of mud and water in the removal plots. However, Sphagnum cover in the removal plots is still very low compared to the thaw ponds. Perhaps these mosses represent a later succession stage, or need more time to establish, as they are not very abundant 
in the direct surroundings of the removal plots. We do not know how old the studied natural thaw ponds are. However, they were present in 2010 (visible on GeoEye very high-resolution satellite image). It is well possible that they have undergone the same vegetation succession trajectory of fast grass expansion at the start of thawing and soil subsidence, followed by ponding of water, B. nana mortality from drowning, and sedge establishment. In the natural thaw ponds, the grass is still present inbetween the open water with drowned shrubs and the living B. nana vegetation (Fig. 7). The natural thaw ponds were also characterized by the presence of Sphagnum moss. Sphagnum is known as an ecosystem engineer creating environmental conditions which halt the expansion of sedges (Heijmans et al. 2002). The moist Sphagnum moss carpet may provide conditions for germination and re-establishment of $B$. nana shrubs (personal observation). The sequence of permafrost degradation and initial vegetation succession in thaw ponds observed in this study is generally in line with the stages of ice-wedge degradation and stabilization described in Jorgenson et al. (2006, 2015a). However, the rapidity of the changes seems to be higher in our study. This could be related to limited soil subsidence in some of the removal plots (Appendix Figure 9), probably linked to lower ice contents. Secondly, the relatively warm summer climate in the extreme continental climate of northeastern Siberia may accelerate the vegetation succession.

Two of the natural thaw pondsare isolated thaw ponds within a shrub patch, whereas the other two thaw ponds are located along the margin of a shrub patch where the permafrost is in contact with flowing water in the adjacent drainage depression. For the isolated thaw ponds it is unknown what caused the abrupt permafrost thaw. The experiment has shown that disturbance of the vegetation can trigger increased thawing initiating a positive feedback loop of soil subsidence, trapping of snow and reduced albedo due to pooling leading to further thawing and thaw pond development (Nauta et al. 2015). Climate warming, flooding and human activities have also been suggested as possible triggers for abrupt thaw (Nauta et al. 2015; Schuur et al. 2015). In the control plots of the removal experiment the thaw depth was deepest in 2011 which was a very wet and also warm summer (Nauta et al. 2015). 2011 was also the year in which the ponding of water in the removal experiment started (Fig. 6), although the removal of B. nana regrowth in 2010 may have contributed to further thawing and soil subsidence as well. Predicted future warmer and wetter conditions could more often trigger abrupt thawing at ice-rich permafrost locations which are not sufficiently protected by the vegetation cover (Shur and Jorgenson 2007).

Thaw ponds emit both $\mathrm{CO}_{2}$ and the strong greenhouse gas methane, whereas shrub vegetation acts as a sink for both greenhouse gases (Nauta et al. 2015; van Huissteden et al. 2005). However, vegetation succession in thaw ponds will probably result in renewal of the $\mathrm{CO}_{2}$ sink when wet sedge vegetation has developed, which may compensate for the high methane emission (van Huissteden and Dolman 2012). This study has contributed new knowledge about the trajectory of thaw pond development and the initial stage of vegetation recovery, which is needed for an assessment of the impact of abrupt permafrost thaw on greenhouse gas emissions. While our research is focusing on north-eastern Siberian tundra, the lowland tundra ecosystem has a wide circumpolar distribution covering most of the coastal plains of the Eurasian and American continents (de Klerk et al. 2014). This tundra zone is considered at high risk of thaw subsidence (Nelson et al. 2001). There are many observations of recent thermokarst, the thawing of ice-rich permafrost causing soil subsidence, redistribution of water and changes in vegetation composition in lowland tundra areas in Alaska (Jorgenson et al. 2006, 2015; Jones et al. 2015), western Canada (Wolter et al. 2016), and eastern Siberia (Fedorov et al. 2014, Liljedahl et al. 2016, Teltewskoi et al. 2016), indicating that abrupt permafrost thaw is widespread. In lowlands, the soil subsidence results in new open water features such as ice wedge troughs, thermokarst pits or thaw ponds in which the pre-existing dwarf shrub vegetation drowns. Although other studies mostly report on ice-wedge degradation, the coupling between relative height, soil moisture conditions and vegetation composition, reported by Jorgenson et al. (2006, 2015), de Klerk et al. (2014) and Wolter et al. (2016), is the same in 
our (developing) thaw ponds. At other sites, the trajectory might be slower and with other plant species, but the processes of permafrost degradation and stabilization are similar (Jorgenson et al. 2006, 2015).

The coastal lowlands of eastern Siberia are known to have abundant thermokarst landforms (Olefeldt et al. 2016) and are classified as highly vulnerable to climate change (Nelson et al. 2001), yet are underreported in English-language scientific literature (Olefeldt et al. 2016). Our observations on permafrost and vegetation dynamics conducted at a north-eastern Siberian tundra site with a relatively warm summer climate could be relevant to assess future landscape changes in currently colder tundra areas as well.

\section{Conclusion}

The nine years of field observations in a unique B. nana shrub removal experiment at a Siberian tundra site illustrated on-going permafrost thaw, albeit at a much slower pace in recent years, and new vegetation changes after 2012. The grass species A. latifolia appeared a fast responder to the abruptly changed light, nutrient and thaw depth conditions caused by the removal treatment, but since 2012 the grass cover is declining. Permanent ponding of water in the subsiding removal plots, resulted in establishment of the sedge species E. angustifolium, which is gradually replacing the grass. The vegetation in the removal plots in the seventh year of the experiment was still different compared to the natural thaw ponds at the same study site, particularly in terms of sedge and Sphagnum cover. However, with the increasing sedge and open water cover the removal plots were becoming increasingly similar to the natural thaw ponds in the recent years. Our well-documented observations in the experiment may represent a trajectory of thaw pond development and the initial stage of vegetation recovery in lowland tundra, which is essential knowledge for an assessment of future landscape changes and the impacts of abrupt permafrost thaw on $\mathrm{CO}_{2}$ and methane emission.

Acknowledgements This study is financed by the Darwin Center for Biogeosciences (grant 142.16.3052), Wageningen Institute for Environment and Climate Research (WIMEK), the Netherlands Organisation for Scientific Research (NWO-ALW, grant 864.09.014) and EU-INTERACT (European Union Seventh Framework Programme, grant 262693). We kindly thank Alexander Kononov and other staff of the IBPC institute, Yakutsk, and staff of the Regional Inspection of Nature Protection of Allaikhovsky Region, Chokurdakh, for logistic support and Luca Belelli Marchesini for providing the meteorological data of the Kytalyk field station.

\section{Appendix}

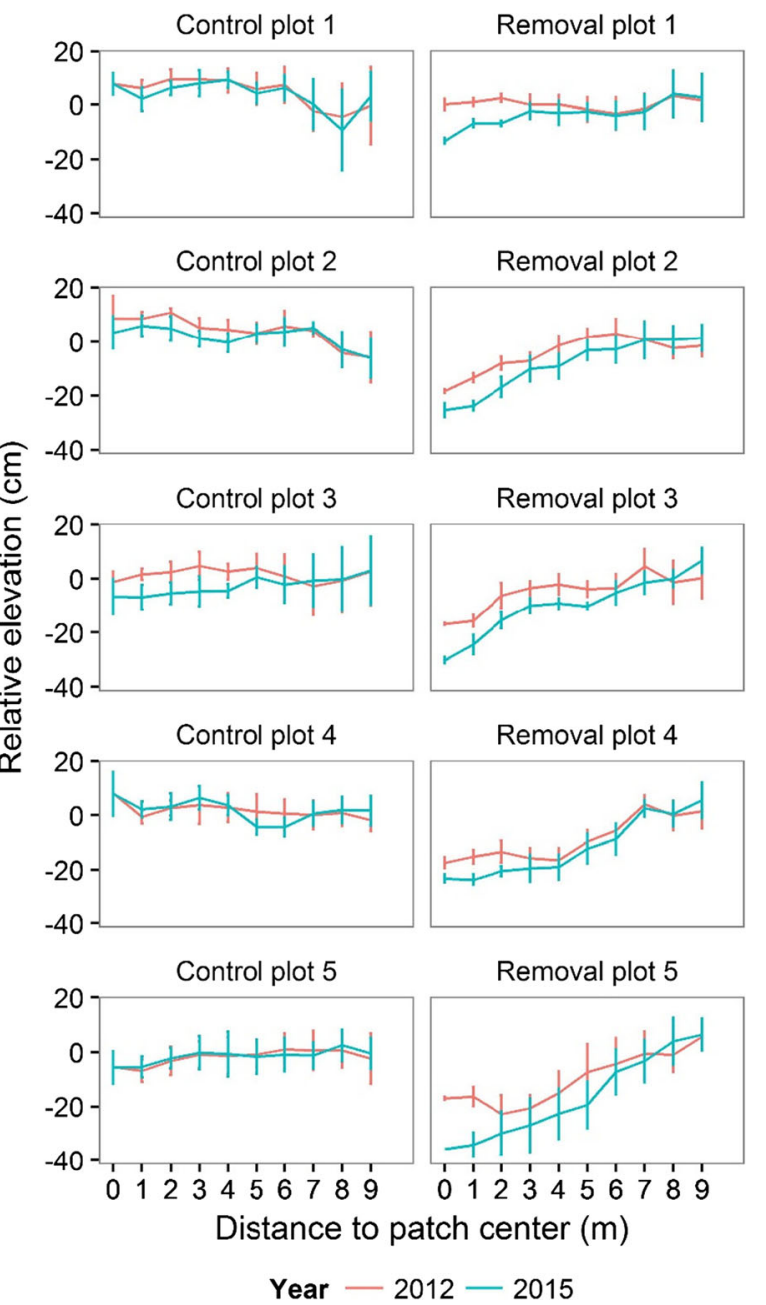

Fig. 9 Relative surface elevation of each plot in the B. nana shrub removal experiment at increasing distance from the plot centre in 2012 and 2015. Data are mean value \pm s.e.m., $n=4$ spots. The red lines are the relative elevation values in 2012 and the blue lines are the relative elevation values in 2015 
Fig. 10 The dendrogram of the correspondence analysis based on the canopy vegetation composition of the plots in the B. nana shrub removal experiment ( 5 control plots and 5 removal plots) and the four natural thaw ponds, all measured in 2013. The closer the plots are to each other in the graph, the higher the similarity in species composition

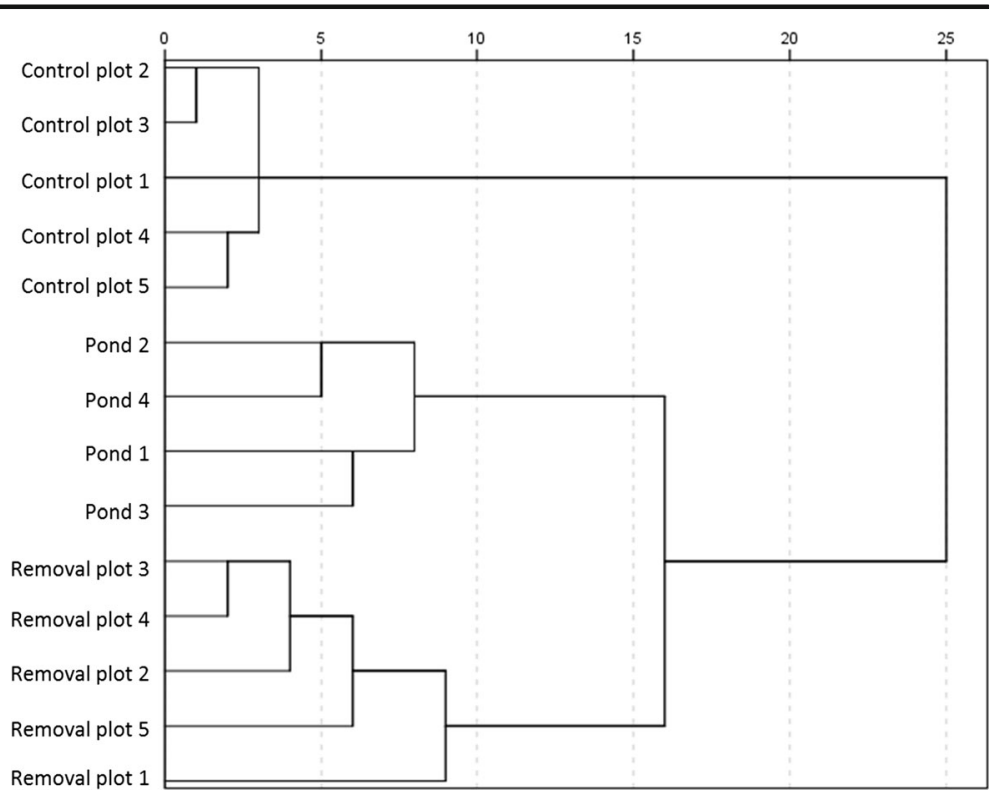

Open Access This article is distributed under the terms of the Creative Commons Attribution 4.0 International License (http:// creativecommons.org/licenses/by/4.0/), which permits unrestricted use, distribution, and reproduction in any medium, provided you give appropriate credit to the original author(s) and the source, provide a link to the Creative Commons license, and indicate if changes were made.

\section{References}

Beck I, Ludwig R, Bernier M, Lévesque E, Boike J (2015) Assessing permafrost degradation and land cover changes (1986-2009) using remote sensing data over Umiujaq, Sub-Arctic Québec. Permafrost \& Periglacial Processes 26:129-141

Bliss LC (1956) A comparison of plant development in microenvironments of Arctic and alpine tundras. Ecol Monogr 26: 303-337

Blok D, Heijmans MMPD, Schaepman-Strub G, Kononov AV, Maximov TC, Berendse F (2010) Shrub expansion may reduce summer permafrost thaw in Siberian tundra. Glob Chang Biol 16:1296-1305

Chapin FS, Shaver GR (1996) Physiological and growth responses of Arctic plants to a field experiment simulating climatic change. Ecology 77:822-840. doi:10.2307/2265504

de Klerk P, Teltewskoi A, Theuerkauf M, Joosten H (2014) Vegetation patterns, pollen deposition and distribution of non-pollen palynomorphs in an ice-wedge polygon near Kytalyk (NE Siberia), with some remarks on Arctic pollen morphology. Polar Biol 37:1393-1412

Dormann CF, Woodin SJ (2002) Climate change in the Arctic: using plant functional types in a meta-analysis of field experiments. Funct Ecol 16:4-17
Elmendorf SC, Henry GHR, Hollister RD, Björk RG, Bjorkman AD, Callaghan TV, Collier LS, Cooper EJ, Cornelissen JHC, Day TA, Fosaa AM, Gould WA, Grétarsdóttir J, Harte J, Hermanutz L, Hik DS, Hofgaard A, Jarrad F, Jónsdóttir IS, Keuper F, Klanderud K, Klein JA, Koh S, Kudo G, Lang SI, Loewen V, May JL, Mercado J, Michelsen A, Molau U, Myers-Smith IH, Oberbauer SF, Pieper S, Post E, Rixen C, Robinson CH, Schmidt NM, Shaver GR, Stenström A, Tolvanen A, Totland Ø, Troxler T, Wahren C-H, Webber PJ, Welker JM, Wookey PA (2012) Global assessment of experimental climate warming on tundra vegetation: heterogeneity over space and time. Ecol Lett 15:164-175. doi:10.1111/j.1461-0248.2011.01716.x

Fedorov AN, Ivanova RN, Park H, Hiyama T, Iijima Y (2014) Recent air temperature changes in the permafrost landscapes of northeastern Eurasia. Polar Science 8:114-128

Fraser RH, Lantz TC, Olthof I, Kokelj SV, Sims RA (2014) Warming-induced shrub expansion and lichen decline in the Western Canadian Arctic. Ecosystems 17:1151-1168

Frost GV, Epstein HE (2014) Tall shrub and tree expansion in Siberian tundra ecotones since the 1960s. Glob Chang Biol 20:1264-1277. doi:10.1111/gcb.12406

Heijmans MMPD, Klees H, Berendse F (2002) Competition between Sphagnum magellanicum and Eriophorum angustifolium as affected by raised $\mathrm{CO}_{2}$ and increased $\mathrm{N}$ deposition. Oikos 97:415-425. doi:10.1034/j.16000706.2002.970311.x

Hinzman L, Bettez N, Bolton WR, Chapin FS III, Dyurgerov M, Fastie C, Griffith B, Hollister R, Hope A, Huntington H, Jensen A, Jia G, Jorgenson T, Kane D, Klein D, Kofinas G, Lynch A, Lloyd A, McGuire AD, Nelson F, Oechel W, Osterkamp T, Racine C, Romanovsky V, Stone R, Stow D, Sturm M, Tweedie C, Vourlitis G, Walker M, Walker D, Webber P, Welker J, Winker K, Yoshikawa K (2005) 
Evidence and implications of recent climate change in northern Alaska and other Arctic regions. Clim Chang 72:251298. doi:10.1007/s10584-005-5352-2

IPCC (2013) Climate Change 2013: the physical science basis. In: Stocker TF, Qin D, Plattner G-K, Tignor M, Allen SK, Boschung J, Nauels A, Xia Y, Bex V, Midgley P (eds) Climate Change 2013. Cambridge University Press, Cambridge

Iwahana G, Takano S, Maximov TC et al (2014) Geocryological characteristics of the upper permafrost in a tundra-forest transition of the Indigirka River Valley, Russia. Polar Science 8:96-113

Jia GJ, Epstein HE, Walker DA (2009) Vegetation greening in the canadian arctic related to decadal warming. J Environ Monit 11:2231-2238. doi:10.1039/B911677J

Jones BM, Grosse G, Arp CD, Liu L, Miller EA, Hayes DJ, Larsen C (2015) Recent arctic tundra fire initiates widespread thermokarst development. Sci Rep 5:15865

Jorgenson MT, Grosse G (2016) Remote Sensing of Landscape Change in Permafrost Regions

Jorgenson MT, Kanevskiy M, Shur Y, Moskalenko N, Brown DRN, Wickland K, Striegl R, Koch J (2015) Role of ground ice dynamics and ecological feedbacks in recent ice wedge degradation and stabilization. J Geophys Res Earth Surf 120: 2280-2297. doi:10.1002/2015JF003602

Jorgenson MT, Marcot BG, Swanson DK, Jorgenson JC, Degange AR (2015) Projected changes in diverse ecosystems from climate warming and biophysical drivers in northwest Alaska. Clim Chang 130:1-14

Jorgenson MT, Romanovsky V, Harden J, Shur Y, O'Donnell J, Schuur EAG, Kanevskiy M, Marchenko S (2010) Resilience and vulnerability of permafrost to climate change. Can J For Res 40:1219-1236. doi:10.1139/X10-060

Jorgenson MT, Shur YL, Pullman ER (2006) Abrupt increase in permafrost degradation in Arctic Alaska. Geophys Res Lett 33:L02503. doi:10.1029/2005GL024960

Kanevskiy M, Shur Y, Krzewinski T, Dillon M (2013) Structure and properties of ice-rich permafrost near Anchorage, Alaska. Cold Reg Sci Technol 93:1-11

Kemper JT, Macdonald SE (2009) Directional change in upland tundra plant communities 20-30 years after seismic exploration in the Canadian low-Arctic. J Veg Sci 20:557-567

Liljedahl AK, Boike J, Daanen RP, Fedorov AN, Frost GV, Grosse G, Hinzman LD, Iijma Y, Jorgenson JC, Matveyeva N (2016) Pan-Arctic ice-wedge degradation in warming permafrost and its influence on tundra hydrology. Nat Geosci 9:312-318

Miller PC, Mangan R, Kummerow J (1982) Vertical distribution of organic matter in eight vegetation types near Eagle Summit, Alaska. Ecography 5:117-124. doi:10.1111/j.16000587.1982.tb01025.x

Murrell P (2003) The grid Graphics Package. https:/www.stat. auckland.ac.nz/ paul/grid/doc/R-1.8.0/uguide_0.8.pdf

Myers-Smith IH, Forbes BC, Wilmking M, Hallinger M, Lantz T, Blok D, Tape KD, Macias-Fauria M, Sass-Klaassen U, Lévesque E, Boudreau S, Ropars P, Hermanutz L, Trant A, Siegwart CL, Weijers S, Rozema J, Rayback SA, Schmidt NM, Schaepman-Strub G, Wipf S, Rixen C, Ménard CB, Venn S, Goetz S, Andreu-Hayles L, Elmendorf S, Ravolainen V, Welker J, Grogan P, Epstein H, E, Hik DS (2011) Shrub expansion in tundra ecosystems: dynamics, impacts and research priorities. Environ Res Lett 6. doi: 10.1088/17489326/6/4/045509

Nauta AL, Heijmans MMPD, Blok D, Limpens J, Elberling B, Gallagher A, Li B, Petrov RE, Maximov TC, van Huissteden J, Berendse F (2015) Permafrost collapse after shrub removal shifts tundra ecosystem to a methane source. Nature Clim Change 5:67-70. doi:10.1038/nclimate2446

Nelson FE, Anisimov OA, Shiklomanov NI (2001) Subsidence risk from thawing permafrost. Nature 410:889-890

Neuwirth E (2014) RColorBrewer: ColorBrewer palettes. R package version 1.1-2

Olefeldt D, Goswami S, Grosse G, Hayes D, Hugelius G, Kuhry P, Mcguire AD, Romanovsky VE, Sannel AB, Schuur EA (2016) Circumpolar distribution and carbon storage of thermokarst landscapes. Nat Commun 7:13043

Oulehle F, Rowe EC, Myška O, Chuman T, Evans CD (2016) Plant functional type affects nitrogen use efficiency in highArctic tundra. Soil Biol Biochem 94:19-28. doi:10.1016/j. soilbio.2015.11.008

Ping CL, Michaelson GJ, Fortier D (2013) Ground ice in the upper permafrost of the Beaufort Sea coast of Alaska. Cold Reg Sci Technol 85:56-70

Robinson CH, Lee JA, Callaghan TVMC, Parsons AN (1995) Growth responses of Calamagrostis lapponica to simulated environmental change in the sub-Arctic. Oikos 72:61-66

Schaefer K, Zhang T, Bruhwiler L, Barrett AP (2011) Amount and timing of permafrost carbon release in response to climate warming. Tellus Series B: Chem Phys Met 63:165-180

Schuur EAG, McGuire AD, Schadel C, Grosse G, Harden JW, Hayes DJ, Hugelius G, Koven CD, Kuhry P, Lawrence DM, Natali SM, Olefeldt D, Romanovsky VE, Schaefer K, Turetsky MR, Treat CC, Vonk JE (2015) Climate change and the permafrost carbon feedback. Nature 520:171-179. doi:10.1038/nature14338

Shaver GR, Chapin FS (1986) Effect of fertilizer on production and biomass of tussock tundra, Alaska, U.S.A. Arct Alp Res 18:261-268

Shaver GR, Cutler JC (1979) The vertical distribution of live vascular phytomass in cottongrass tussock tundra. Arct Alp Res 11:335-342. doi:10.2307/1550421

Shaver GR, Johnson LC, Cades DH, Murray G, Laundre JA, Rastetter EB, Nadelhoffer KJ, Giblin AE (1998) Biomass and $\mathrm{CO} 2$ flux in wet sedge tundras: responses to nutrients, temperature, and light. Ecol Monogr 68:75-97

Shur Y, Jorgenson MT (2007) Patterns of permafrost formation and degradation in relation to climate and ecosystems. Permafrost Periglac Proc 18:7-9. doi:10.1002/PPP.582

Siewert MB, Hanisch J, Weiss N, Kuhry P, Maximov TC, Hugelius G (2015) Comparing carbon storage of Siberian tundra and taiga permafrost ecosystems at very high spatial resolution. J Geophys Res Biogeosci 120(10):1973-1994. doi:10.1002/2015JG002999

Tape KEN, Sturm M, Racine C (2006) The evidence for shrub expansion in Northern Alaska and the Pan-Arctic. Glob Chang Biol 12:686-702. doi:10.1111/j.13652486.2006.01128.x 
Tarnocai C, Canadell JG, Schuur EAG, Kuhry P, Mazhitova G, Zimov S (2009) Soil organic carbon pools in the northern circumpolar permafrost region. Glob Biogeochem Cycles 23: 2607-2617

Teltewskoi A, Beermann F, Beil I, Bobrov A, de Klerk P, Lorenz S, Luder A, Michaelis D, Joosten H (2016) 4000 years of changing wetness in a permafrost polygon peatland (Kytalyk, NE Siberia): a comparative high-resolution multi-proxy study. Permafrost Periglac Proc 27:76-95

van Huissteden J, Dolman AJ (2012) Soil carbon in the Arctic and the permafrost carbon feedback. Curr Opin Environ Sustain 4:545-551

van Huissteden J, Maximov TC, Dolman AJ (2005) High methane flux from an arctic floodplain (Indigirka lowlands, eastern Siberia). J Geophys Res Biogeosci 110:565-571

Walker DA, Raynolds MK, Daniëls FJA, Einarsson E, Elvebakk A, Gould WA, Katenin AE, Kholod SS, Markon CJ, Melnikov ES, Moskalenko NG, Talbot SS, Yurtsev BA, The other members of the CT (2005) The circumpolar Arctic vegetation map. J Veg Sci 16:267-282. doi:10.1111 /j.1654-1103.2005.tb02365.x
Wang P, Limpens J, Mommer L, van Ruijven J, Nauta AL, Berendse F, Schaepman-Strub G, Blok D, Maximov TC, Heijmans MMPD (2017) Above- and below-ground responses of four tundra plant functional types to deep soil heating and surface soil fertilization. J Ecol. doi:10.1111 /1365-2745.12718

Wang P, Mommer L, van Ruijven J, Berendse F, Maximov TC, Heijmans MMPD (2016) Seasonal changes and vertical distribution of root standing biomass of graminoids and shrubs at a Siberian tundra site. Plant Soil 407:55-65. doi:10.1007 /s11104-016-2858-5

Wickham H (2012) scales: Scale functions for graphics. R package version 0.23

Wickham H (2016) ggplot2: Elegant Graphics for Data analysis. Springer. Doi: 10.1007/978-3-319-24277-4_1

Wolter J, Lantuit H, Fritz M, Macias-Fauria M, Myers-Smith I, Herzschuh U (2016) Vegetation composition and shrub extent on the Yukon coast, Canada, are strongly linked to icewedge polygon degradation. Polar Res 35:27489 